\title{
CHARACTERIZATION OF DUST SAMPLES FROM A COAL STRIP MINE USING A RESUSPENSION CHAMBER
}

\author{
MARTIN CIVIŠ, DEVRAJ THIMMAIAH, and JAN HOVORKA*
}

Institute for Environmental Studies, Faculty of Science, Charles University, Benátská 2, 12801 Prague 2, Czech Republic

* Corresponding author: jan.hovorka@natur.cuni.cz

\section{ABSTRACT}

\begin{abstract}
A metallic cylindrical resuspension chamber $\left(\mathrm{V}=0.437 \mathrm{~m}^{3}, \mathrm{~S}=0.35 \mathrm{~m}^{2}, \mathrm{~S} / \mathrm{V}=8.38\right)$ was constructed to disperse samples of soil and various kinds of dust. The chamber allows on-line determination of number/mass size distribution of aerosol particles formed by dispersion and subsequent sampling of size-segregated particles on filter media. The samples tested were lignite, power plant flue ash and overburden soil from the Nastup coal strip mine in Northern Bohemia. About $20 \mathrm{mg}$ of the individual samples were pneumatically dispersed by 0.5 liter of pressurized air inside the chamber under defined temperature and humidity conditions. Then the dynamics of aerosol size distributions was recorded using an aerodynamic particle sizer with a frequency of 5 seconds. The lignite and flue ash contributed most to the mass of atmospheric aerosol particles smaller than 10/2.5 micrometer - $\mathrm{PM}_{10} / \mathrm{PM}_{2.5}$. The re-suspended mass of the samples varied between $0.001 \%$ for overburden soil and $0.32 \%$ for mine road soil. The aerosolized lignite and flue ash samples, sampled by a Harvard Impactor and a Personal Cascade Impactor Sampler, revealed that the ash contained higher amounts of fine particles than the lignite and subsequent chemical analyses, carried out using SEM-EDX, reveals that the $\mathrm{PM}_{2.5}$ fraction formed by dispersion of the ash samples had the highest content of sulphur, and $\mathrm{PM}_{10}$ was dominated by $\mathrm{Si}$. $\mathrm{PM}_{10}$ was closest to mullite, while the $\mathrm{PM}_{2.5}$ fraction contained sulphides, pyrites, pyrrhotites and polytypes of sulphide. The $\mathrm{PM}_{1}$ fraction was dominated by quartz glass. The fractions of sizes $2.5-1 \mu \mathrm{m}$ and $0.5-0.25 \mu \mathrm{m}$ were dominated by Si and S, respectively.
\end{abstract}

Keywords: fugitive dust, fly ash, pulverized coal, aerosol wettability

\section{Introduction}

The atmospheric aerosol, the colloid formed by the dispersion of solids and/or liquids in the gaseous coat of the Earth, has been a subject of interest since the end of the 1930s. A key source of coarse particles in the atmospheric aerosol is the dust produced by numerous surfaces and processes such as deserts, agricultural areas, road surfaces, devastated landscapes, volcanic eruptions, building sites and industrial zones. Aerosols are also produced worldwide in mining and industrial combustion processes. But in contrast to combustion-related aerosols (Ning et al. 2010) the dynamics of atmospheric processes in the resuspension-related aerosol is much simpler. Atmospheric aerosol pollution, with concentrations often exceeding current health limits, is among the most serious problems in air quality both globally and locally (Thimmaiah et al. 2009) in the Czech Republic. While the effects of gaseous pollutants on human health have been sufficiently studied and recorded, much less is known about the origin, behaviour and effects of the aerosol particles. Many studies have shown that aerosol particles have a negative effect on human health and vegetation (Dockery et al. 1993; Pope et al. 1995). Most countries have converted from the original method of aerosol sampling, Total Suspended Particles (TSP), which does not differentiate between particles of different sizes, to the socalled thoracic fraction of the aerosol $\mathrm{PM}_{10}$. This method uses a front-end device for measuring, with an efficiency of $50 \%$, the particles on a filter that have an aerodynamic diameter of $10 \mu \mathrm{m}$. A study published in the 1990s re- ports that concentrations of $\mathrm{PM}_{2.5}$ are more strongly correlated with the negative effects on human health than $\mathrm{PM}_{10}$ (Schwartz et al. 1996). This has led to the regulation of $\mathrm{PM}_{\mathrm{x}}$ emissions and the setting of emission limits for aerosol particles in the USA and the EU. Globally, the current trend is to change to measuring the aerosol fraction $\mathrm{PM}_{1.0}$ and to consider the relationship between the number of particles and their size.

The TSP and also the $\mathrm{PM}_{10}$ have been continually monitored for many years by the Czech Hydrometeorological Institute and the National Institute of Public Health. $\mathrm{PM}_{10}$ and $\mathrm{PM}_{2.5}$ are emitted into the atmosphere primarily by high-temperature processes, secondarily by gas-particle conversion and thirdly by resuspension of existing, already deposited matter. While the first two processes add mostly to the fine fraction $\mathrm{PM}_{2.5}$, the resuspension contributes to the coarse fraction. Resuspension is a significant source of aerosol for both local and intercontinental air masses.

The generation, capture and measurement of particles in a controlled laboratory environment are very important for determining the emission potentials of different sources of dust and for defining the physical characteristics, chemical composition and toxicological risk connected with the emission of particles into the atmosphere from specific locations or source materials.

During the twentieth century, many researchers described devices for producing or re-suspending dust. These devices were designed for various purposes: e.g., for the simulation of contaminated air inside a dusty factory (Dahmann et al. 1997), the control of industrial pro- 
cesses ASTM (1984), in the pharmaceutical industry for the development of dry inhalers that maximize the concentration of fine aerosol in order to achieve the longest possible path of the particles inside the respiratory tract after inhalation (Hindle et al. 1995; Concessio et al. 1997; Newman et al. 2002; Newman et al. 2004), for the exposure of laboratory animals to high concentrations of mineral aerosols in studies on respiratory diseases $(\mathrm{Mu}-$ hle et al. 1990), for the preparation of samples for chemical analyses (Morales et al. 1994), for the measurement of the ecophysiological effect of dust on leaves (Hirano et al. 1995) and simulating the penetration of solid particles into buildings (Lewis 1995; Chen et al. 1999). For many years, standard dusts were prepared, with different sizes of particles and different indices of light refraction. These standards were used in tests of the capture effectiveness of filtration devices and for testing optical devices measuring the dispersion of light by aerosol particles. The most widely known is Arizona Dust, which has been used since the 1940s (SAE Handbook 1943). However, few devices have been designed that specifically examine the contribution of dust or mineral aerosols to the total concentration of aerosol in the atmosphere.

One of the first laboratory devices for measuring dust production from different materials was designed and built by the German researchers Andreasen, Hofman-Bang and Rasmussen (1939). Their experiment used a long, thin-walled tube in which they measured the precipitation time of particles of various materials and deduced their sizes from Stokes Law. That study also reports the first measurements of the fractionation of particles from the parent material under different conditions of relative humidity and moisture. Their device is considered the precursor of the whole series of modern devices for producing dust and for observing the free fall of particles of various sizes (Cheng 1973; Sutter et al. 1982; Heitbrink et al. 1992; Lanning 1995). Subsequent dust formation devices used the principle of vibration screening (Deichman et al. 1944; Sonkin et al. 1946), or produce dust by means of a scraper that breaks the material mounted on a rotating cylinder (Graham et al. 1985).

The majority of laboratory methods dealing with the production of dust from a parent material or with resuspension in relation to the atmospheric aerosol (both in interior and exterior environments) use physical sampling on filtration media with a subsequent gravimetric analysis. The literature contains very few examples of other techniques, such as those based on optical sensors (Li et al. 1996) or a Tapered-Element Oscillating Microbalance (Busacca et al. 1997; Breum 1999).

In this work, we describe the construction of a resuspension chamber used for the dispersion of samples of soil, dust and standard aerosol materials found in the air, under clearly defined temperature-humidity conditions. The main aim of this work is to utilize the device for the dispersion of soil samples from the coal strip mine Nastup in Northern Bohemia and to determine the size distribution of particle number and particle mass in the individual samples.

\section{Material and Methods}

The resuspension chamber is made of hot-dip galvanized steel. Its volume $(\mathrm{V})$ is $0.437 \mathrm{~m}^{3}$, the inner surface area is $0.35 \mathrm{~m}^{2}$ and the $\mathrm{S} / \mathrm{V}$ ratio is 8.38 . A detailed diagram is shown in Fig. 1.

Two asynchronous ventilators with a regulated power of $15 \mathrm{~W}$, which can be used to create a turbulent environment, are positioned opposite each other in the center of the chamber walls. The ventilators are suspended on rotating heads, allowing the particles to be kept airborne (at $5 \mathrm{~m} \mathrm{~s}^{-1}$ ), or to have their deposition increased in a turbulent environment. The ventilators were not used in our experiments.

Bushings of diameter $100 \mathrm{~mm}$, with mechanically operated flaps, are located in the upper and lower bases. The upper bushing is joined to a flexible double-walled, heat-insulated aluminum hose, which supplies air from the humidifier and spiral heater at the desired humidity $(20-80 \%)$ and temperature $\left(15-40{ }^{\circ} \mathrm{C}\right)$. The lower bushing is connected to a similar hose which encloses the circuit, taking the air from the chamber back to the humidifier. This regulated air circulation allows the required temperature-humidity conditions to be reached inside the chamber. The air humidity is controlled by a commercial ultrasound humidifier using distilled water. The humidifier is positioned in a separate galvanized vessel with one outlet and two inlets. Each inlet is equipped with a regulated ventilator $(15 \mathrm{~W})$ and a manually operated flap. The dispersed water droplets are captured in a porous sponge. Some ultra-fine particles can, under certain conditions, leak through the sponge (Vincent et al. 1993), but in our case the dispersed water droplets had sufficient size to be captured with high efficiency. The capture efficiency reached near $100 \%$, as tested by an aerosol spectrometer. The diagram of the humidifier vessel is shown in Fig. 2.

The air is cleaned by a front-end HEPA filter and the humidity of the incoming air is removed by silica gel. Fig. 1 shows the detailed schema of the resuspension chamber.

Prior to suspension, the samples were dried at a temperature of $40{ }^{\circ} \mathrm{C}$ and then sieved through a $0.037 \mathrm{~mm}$ mesh size Tyler screen. Then the samples were weighed into a special glass vial, which has 4 jets at the base. The vial is inserted into a bushing in the center of the upper part of the chamber. After the required temperature-humidity conditions are reached inside the chamber, the sample is pneumatically dispersed by 0.51 of dried compressed air from a pressurized bottle (kept at 9-10 atm); the velocity of the flow through the jets reaches $6 \mathrm{~m} \mathrm{~s}^{-1}$. 


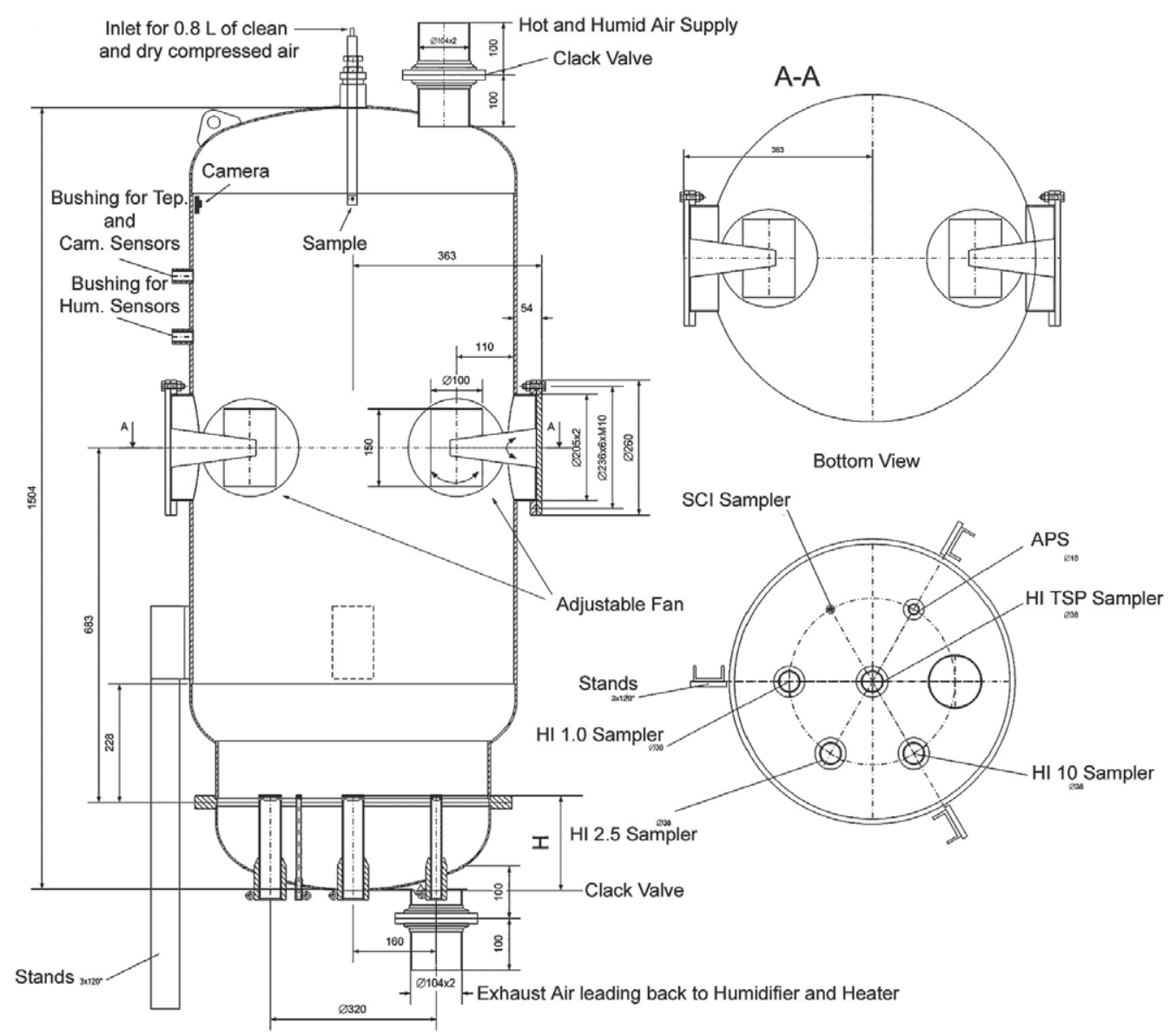

Fig. 1 Diagram of the resuspension chamber.
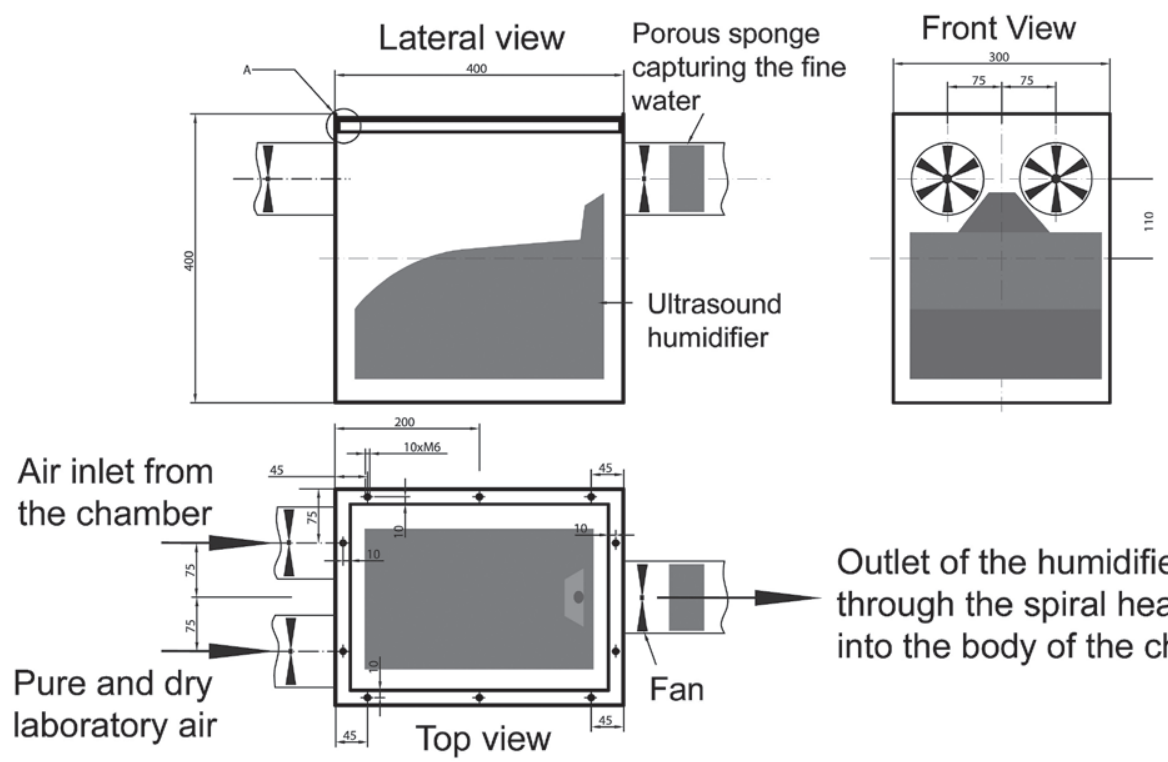

Outlet of the humidifier air through the spiral heater into the body of the chamber

Fig. 2 Diagram of the peripheral vessel with the humidifier.

The process of suspension can be monitored using a camera, which is placed inside the chamber.

The lower base of the chamber is completely removable after loosening the screw joint, which is sealed with a rubber seal. The base can hold sampling heads of various diameters, depending on the measurement (see Fig. 3).

\section{Devices Used in the Experiment}

The aerosol produced by the dispersion of a sample was observed using an Aerodynamic Particle Sizer, APS model 3321, which monitored the size distributions of particles in the range of 0.524 to $20 \mu \mathrm{m}$. Depending on the suspendable quantities of the individual samples, the 


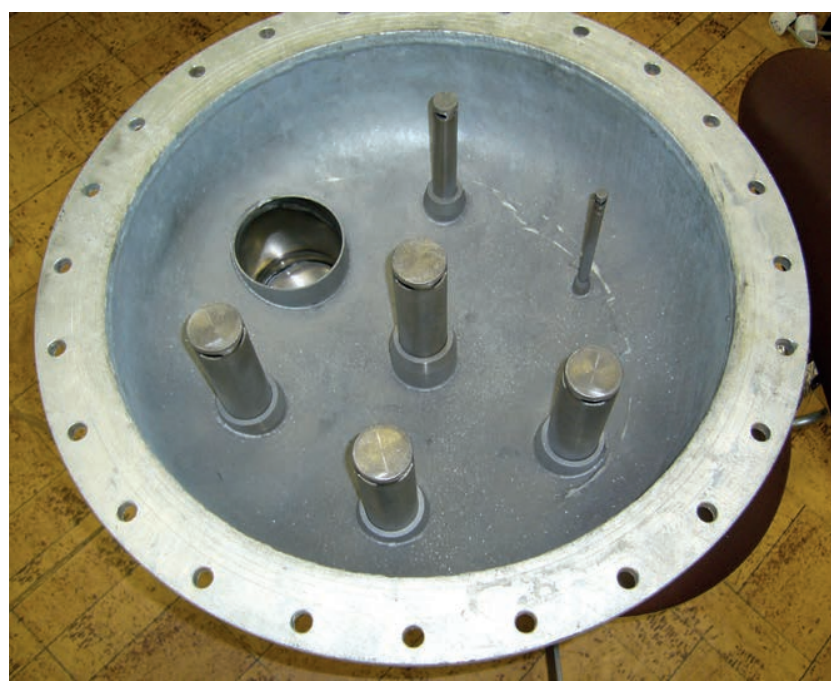

Fig. 3 Sampling heads in the removable base of the resuspension chamber.

analyzed aerosol must be diluted with clean air before it enters the APS, so that the aerosol/air ratio is $1 / 6.7$. The APS inlet has a side feed of diluting air with an adjustable flow rate and a front-end HEPA filter.

Selected samples were gravimetrically analyzed using Harvard impactors (Marple et al. 1987), TSP and a Personal Cascade Impactor Sampler, PCIS (Misra et al. 2002). The resulting size fractions and the air flow rate are given in Table 1. After the dispersion, the samples were separated and captured on one $37 \mathrm{~mm}$ and four $25 \mathrm{~mm}$ polytetrafluorethylene (PTFE) pre-weighed fil- ters. The filters with deposited aerosol were chemically analyzed. Before each weighing, the filters were kept in a desiccator at close to $50 \%$ humidity and $21^{\circ} \mathrm{C}$ (saturated $\mathrm{KNO}_{3}$ ). During the gravimetric analyses, the exhausted air was replaced with new air with the required temperature-humidity characteristics. The laminar flow created by the gravimetric sampling reached velocities of around $0.003 \mathrm{~m} \mathrm{~s}^{-1}$. If all gravimetric sampling devices were used, the studied air would be exhausted within $8 \mathrm{~min}$ utes. During the aerosol analysis using the APS, the analyzed air is highly diluted, the sampling flow rate is low $\left(0.121 \mathrm{~min}^{-1}\right)$ and therefore the influence of the dilution of the studied aerosol by the new air can be neglected. A large air flow rate through the chamber during sampling for gravimetric analyses and the determination of mass concentrations of the individual size fractions would require using the correction component for ventilation. However, in our case, gravimetric methods were used to measure changes in the mass of individual size fractions at different temperature-humidity conditions. The masses were evaluated as percentage ratios between TSP and mass values of the individual size fractions. In this way, the use of the aerosol dynamic equations could be avoided.

A scanning Electron Microscope, SEM (Hitachi S-4800) coupled Energy Dispersive Spectroscopy, EDS (Noran System Six software, Thermo Electron Corp., USA) was used to view and analyze aerosol on Teflon filters. A deposit area of $0.36 \mathrm{~mm}^{2}$ on the filter $(0.6 \times 0.6 \mathrm{~mm})$ was analyzed.

Table 1 List of impactors used.

\begin{tabular}{|l|c|c|c|c|c|c|}
\hline & \multicolumn{5}{|c|}{ Size Fraction } & Air Flow [I min $\left.{ }^{-1}\right]$ \\
\hline Harvard Impactor & TSP & PM10 & PM2.5 & PM1 & & 10 \\
\hline Sioutas Cascade Impactor & $>2.5 \mu \mathrm{m}$ & $2.5-1.0 \mu \mathrm{m}$ & $1.0-0.5 \mu \mathrm{m}$ & $0.5-0.25 \mu \mathrm{m}$ & $<0.25 \mu \mathrm{m}$ & 9 \\
\hline Aerodynamic Particle Sizer & \multicolumn{7}{|c|}{$0.5-20 \mu \mathrm{m}(52$ channels $)$} & 1 \\
\hline
\end{tabular}

Table 2 List of samples collected at the Nastup coal strip in Northern Bohemia.

\begin{tabular}{|c|c|c|c|c|c|c|}
\hline \multirow{2}{*}{$\begin{array}{c}\text { Sample } \\
1\end{array}$} & \multirow{2}{*}{$\begin{array}{l}\text { Locality } \\
\text { Homogenized lignite }\end{array}$} & \multicolumn{2}{|c|}{ Position } & \multirow{2}{*}{$\begin{array}{c}\begin{array}{c}\text { Mass Density } \\
{\left[\mathbf{k g ~ m}^{-3}\right]}\end{array} \\
1.66\end{array}$} & \multirow{2}{*}{$\begin{array}{c}\begin{array}{c}\% \text { of mass } \\
\text { after sieving }\end{array} \\
5.31\end{array}$} & \multirow{2}{*}{$\begin{array}{c}\begin{array}{c}\text { Mass for } \\
\text { Suspension [mg] }\end{array} \\
10\end{array}$} \\
\hline & & E 13.33299 & N 50.40022 & & & \\
\hline 2 & Coal stacker & E 13.33890 & N 50.41228 & 2.65 & 0.96 & 10 \\
\hline 3 & Lignite mine bed & E 13.32273 & N 50.42746 & 1.66 & 2.41 & 10 \\
\hline 4 & Coal dust from the road & E 13.32273 & N 50.42746 & 1.66 & 16.81 & 10 \\
\hline 5 & Coal mine & E 13.32727 & N 50.42886 & 1.66 & 1.05 & 10 \\
\hline 6 & Road in the coal mine & E 13.32727 & N 50.42886 & 1.66 & 6.55 & 10 \\
\hline 7 & Dumping site for ash & E 13.28177 & N 50.42273 & 2.22 & 10.32 & 10 \\
\hline 8 & Dumping site for gypsum & E 13.27959 & N 50.41076 & 2.94 & 3.28 & 10 \\
\hline 9 & Ash-fresh & E 13.27959 & N 50.41076 & 2.32 & 16.32 & 10 \\
\hline 10 & Capping soil & E 13.38563 & N 50.40848 & 2.73 & 0.41 & 10 \\
\hline 11 & Ash from Tušimice powerplant & E 13.37946 & N 50.38382 & 2.65 & 6.77 & 10 \\
\hline
\end{tabular}




\section{Field Sampling}

1-2 $\mathrm{kg}$ samples were sampled at the coal strip mine Nastup in the Northern Bohemia $(50.415232 \mathrm{~N}$, 13.343338E) from different parts of the mine such as mine roads, coal dump, mining locations, flue ash dump, gypsum dump and the soil used for covering flue ash and gypsum dumps. The aim was to find which parts of the mine contribute most to aerosol particle emission. Table 2 lists the samples, their geographical location, virtual density, percentage of mass remaining after 2 hours drying at $40{ }^{\circ} \mathrm{C}$ and subsequent sieving through a Tyler screen, and the sample weight used for suspension.

In total, five dispersions of each sample were carried out in the resuspension chamber at $20^{\circ} \mathrm{C}$ and RH $50 \%$. The individual size distributions of particle number and mass were measured with $2 \mathrm{~s}$ time resolution for the duration of 10 minutes. The first 5 minutes (150 distributions) of each dispersion were subsequently selected (5 dispersions of each sample in total). This selection provided us with data for calculating the average size distribution (from the total number of 750 distributions) of particle mass and number related to the individual samples.

The lignite samples were also studied by gravimetric analysis using the $\mathrm{HI}$ under varied time-humidity conditions. The lignite and flue ash samples were then analyzed at $20{ }^{\circ} \mathrm{C}$ and $\mathrm{RH} 50 \%$ using the $\mathrm{HI}$ and the PCIS, and their size distributions of mass were determined as ratios of individual fractions to the TSP. Elemental analysis using electron microscopy and X-ray energy dispersive spectrometry (EDS) was carried out using the flue ash deposited on the filters.

\section{Results and Discussion}

Figs 4 to 14 show the average size distributions of particle number and mass of the individual samples dis-

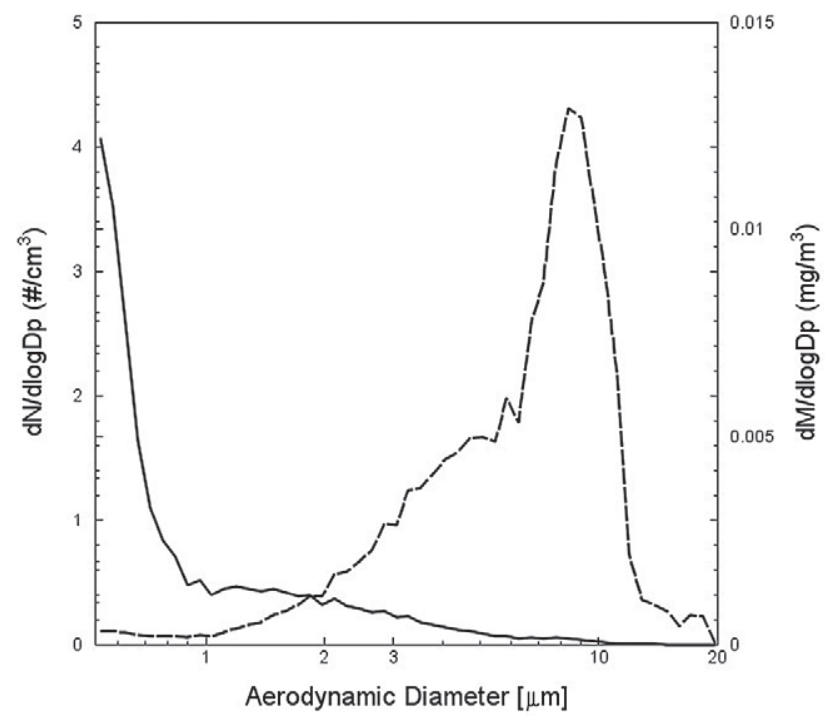

Fig. 4 Sample 1, Homogenized Lignite: continuous line - number size distribution, dashed line - mass size distribution. persed in the resuspension chamber. Tables 3 to 5 give the statistical values for the average size distributions of particle number and mass including the CMD (count median diameter) or MMD (mass median diameter), respectively, of the aerosol particles.

The data show that the highest average particle number and mass concentrations are those recorded for flue ash (Figs 10 and 14), which is normally disposed of as landfill in the exhausted parts of the surface mine. If the sieved sample $(10 \mathrm{mg})$ becomes airborne in the chamber, the mass concentration would reach $22.88 \mathrm{mg} \mathrm{cm}^{-3}$ or as a percentage of the dispersed matter: $2.58 \%$ for sample 7 and $2.71 \%$ for sample 11 (Table 4 and 5). The effectively dispersed portions as percentages of the total mass of the dry samples are $0.26 \%$ for sample 7 and $0.19 \%$ for sample 11. The mass concentrations of dispersed matter reached by other samples were $0.34 \%$ (sample 8 - gypsum) and $1.88 \%$ (sample 4 - mine surface). The average number concentration for sample 7 reached as high as 70 particles per $\mathrm{cm}^{3}$. The size distribution had two peaks, the first around $0.5 \mu \mathrm{m}$ and the second around $1.3 \mu \mathrm{m}$. The average mass concentration reached by the flue ash sample was $0.59 \mathrm{mg} \mathrm{m}^{-3}$ and the size distribution had two peaks, the first at $4 \mu \mathrm{m}$ and the second at $10 \mu \mathrm{m}$. The flue ash is transported by conveyor belt directly to the exhausted parts of the lignite mine from the Tusimice power plant. After reaching the end of belt, it is loosely poured onto the dump, where it should be subsequently covered with overburden soil. The ash samples were also gravimetrically analyzed using HI and PCIS.

The average number concentrations of road lignite dust (sample 4, Table 3) reached 60 particles per $\mathrm{cm}^{3}$ with a peak around $1.6 \mu \mathrm{m}$ (Fig. 9) and the mass concentrations were $0.43 \mathrm{mg}$ per $\mathrm{cm}^{3}$ with two peaks at $3.3 \mu \mathrm{m}$ and $10 \mu \mathrm{m}$ (Table 3 ). The mine roads are used by heavy machinery, which breaks up the lignite (sample 5 - Fig. 8) deposited on the road surfaces from particles with an

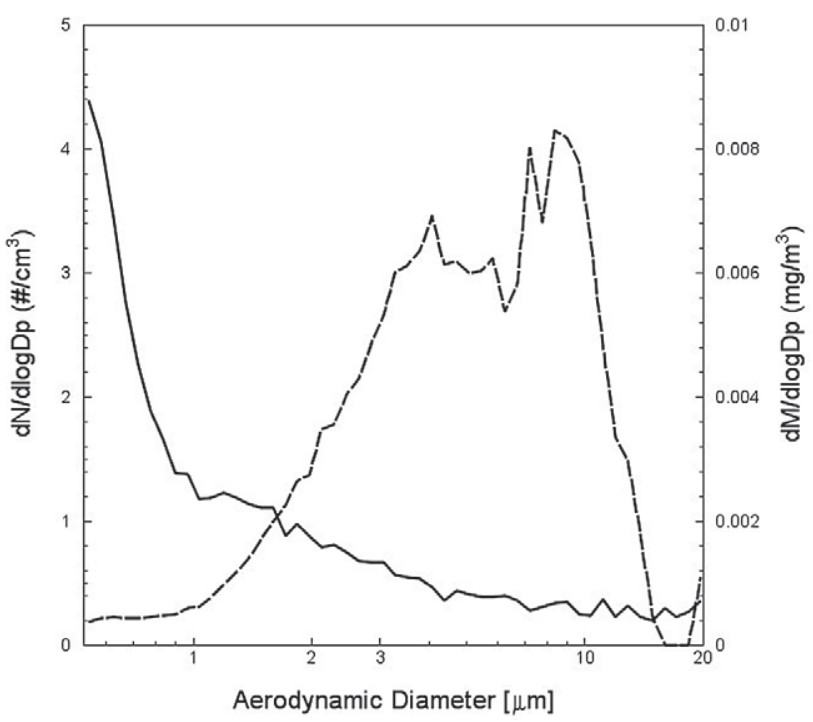

Fig. 5 Sample 2, Coal Stacker: continuous line - number size distribution dashed line - mass size distribution. 


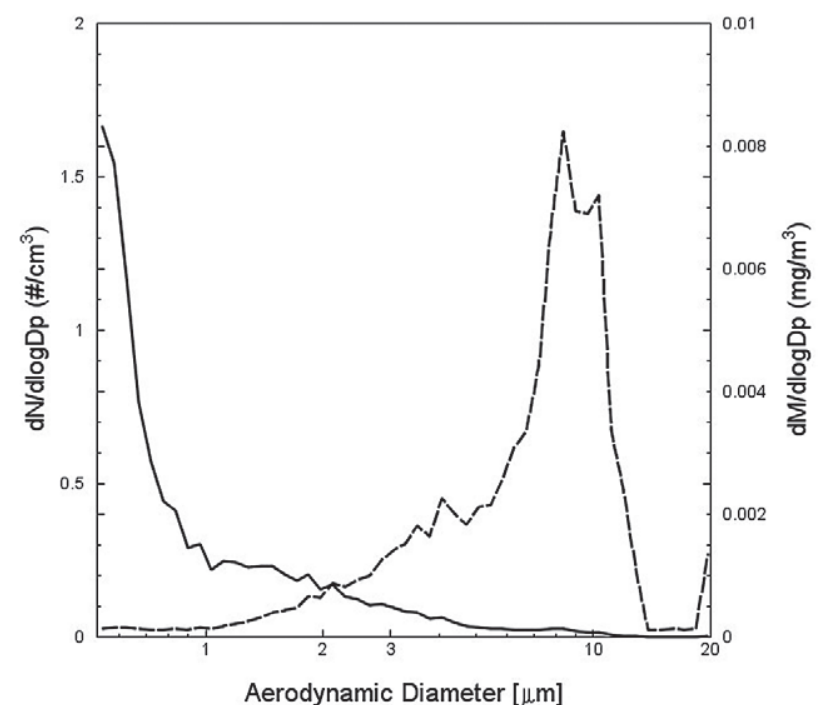

Fig. 6 Sample 3, Lignite Mine Bed: continuous line - number size distribution, dashed line - mass size distribution.

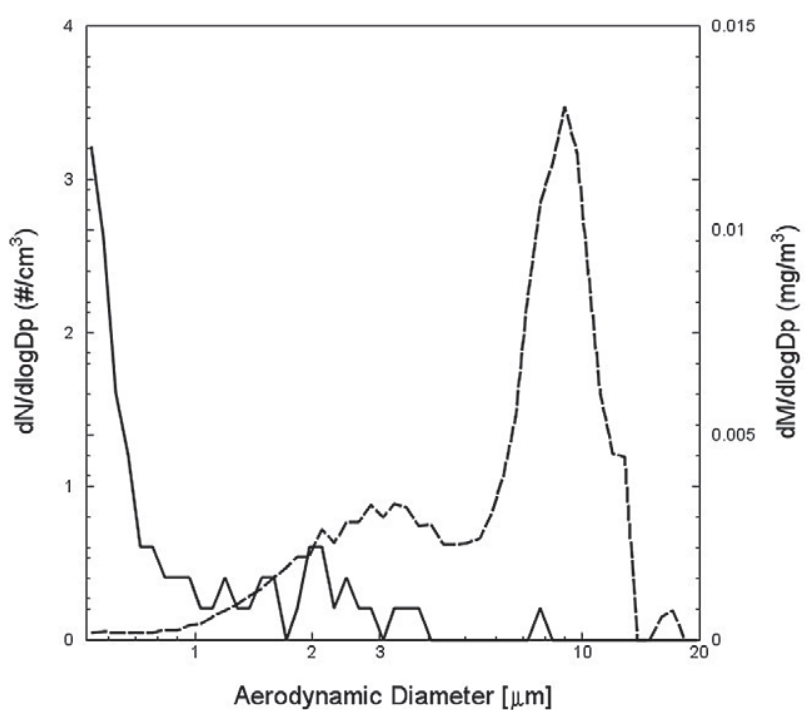

Fig. 8 Sample 5, Coal Mine: continuous line - number size distribution, dashed line - mass size distribution.

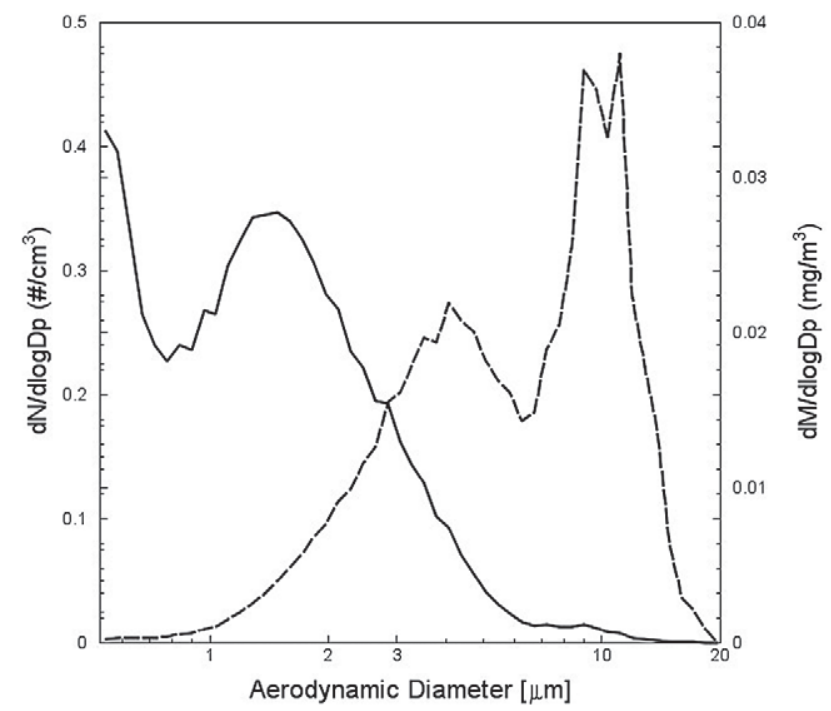

Fig. 10 Sample 7, Dumping Site for Ash: continuous line - number size distribution, dashed line - mass size distribution.

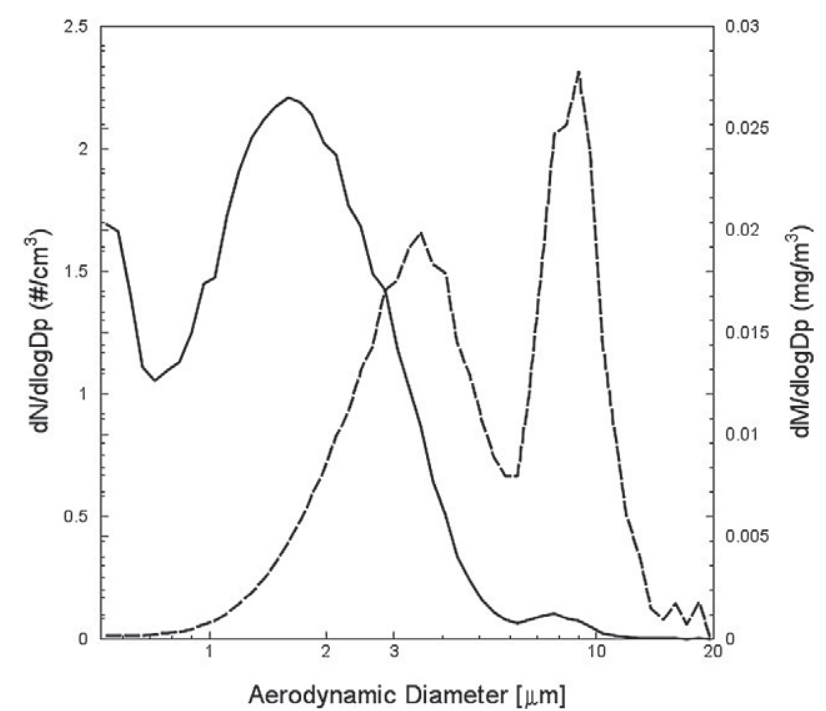

Fig. 7 Sample 4, Coal Dust from the Road: continuous line - number size distribution, dashed line - mass size distribution.

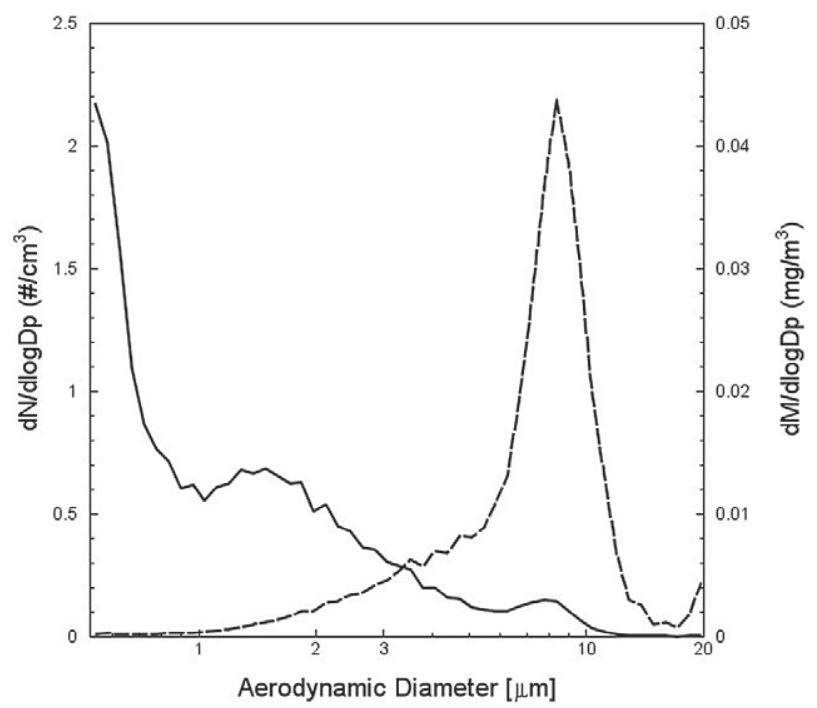

Fig. 9 Sample 6, Road in the Coal Mine: continuous line - number size distribution, dashed line - mass size distribution.

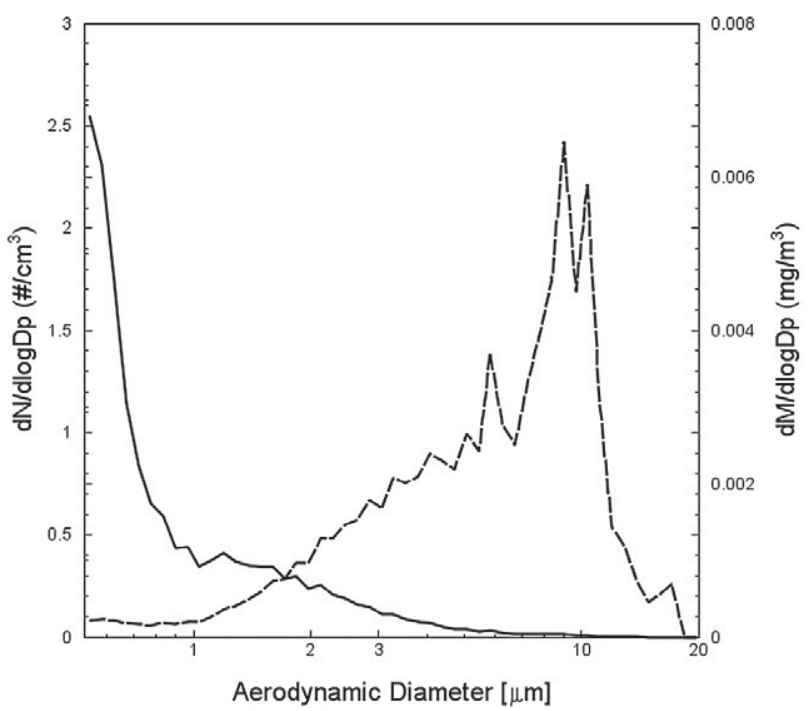

Fig. 11 Sample 8, Dumping Site for Gypsum: continuous line - number size distribution, dashed line - mass size distribution. 


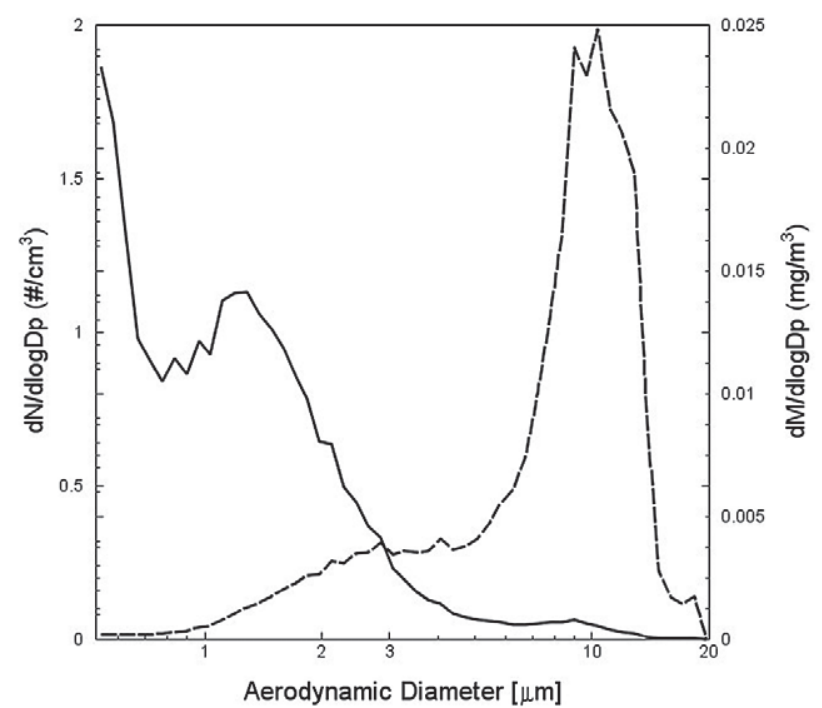

Fig. 12 Sample 9, Dumping Site for Fresh Ash: continuous line - number size distribution, dashed line - mass size distribution.

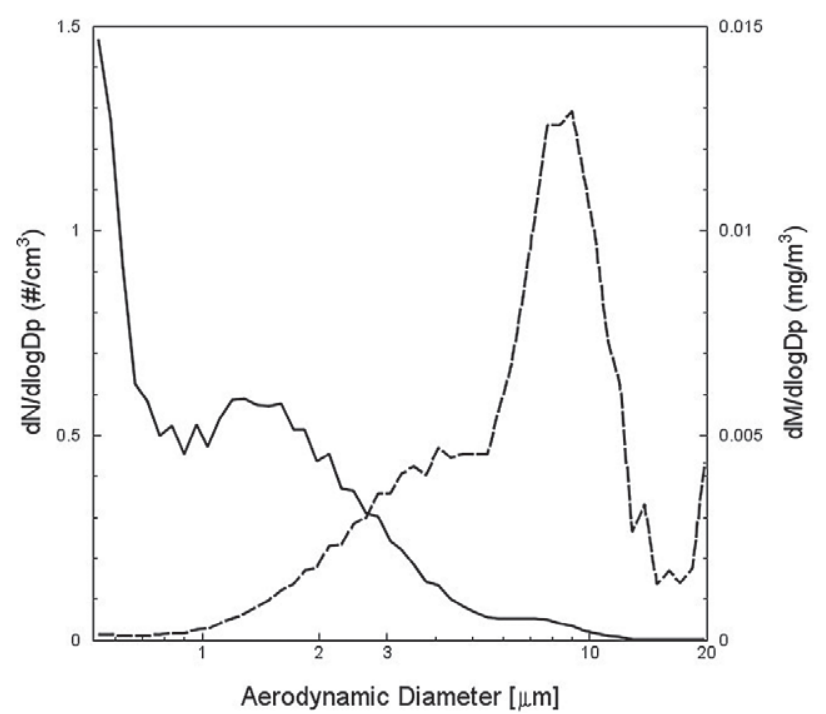

Fig. 13 Sample 10, Capping Soil: continuous line - number size distribution, dashed line - mass size distribution.

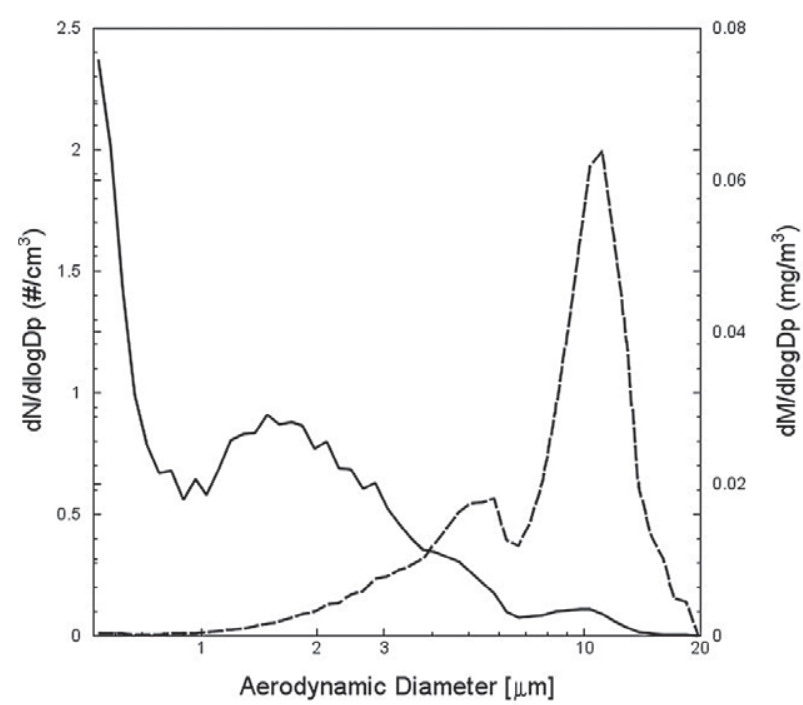

Fig. 14 Sample 11, Ash from Tušimice power plant: continuous line number size distribution, dashed line - mass size distribution.

original size of around $10 \mu \mathrm{m}$ into smaller particles with sizes around $3.3 \mu \mathrm{m}$ (sample $4-$ Fig. 7). The final result of this process is that the total mass concentration of atmospheric aerosol is largely affected by the presence of these particles from the mine roads (Fig. 7), rather than the particles originating from the direct mining process or the flue ash dump.

The smallest average mass concentration of particles suspended in the resuspension chamber was reached by the sample of gypsum used in the desulphurization process. The average mass concentration was only $0.08 \mathrm{mg} \mathrm{m}^{-3}$ $(0.34 \%$ of the theoretically possible sample weight and only $0.01 \%$ of the total sample mass was dispersed). The gypsum dumps therefore have the least influence on the total mass concentration of atmospheric aerosol.

Fig. 15 shows a map of the North Bohemian lignite mine and indicates the sampling locations. The locations are colour-coded according to the percentage of dis-

Table 3 Sample 1-4.

\begin{tabular}{|c|c|c|c|c|c|c|c|c|}
\hline \multirow[b]{3}{*}{ Sample Name } & \multicolumn{2}{|c|}{1} & \multicolumn{2}{|c|}{2} & \multicolumn{2}{|c|}{3} & \multicolumn{2}{|c|}{4} \\
\hline & \multicolumn{2}{|c|}{ Homogenized Lignite } & \multicolumn{2}{|c|}{ Coal Stacker } & \multicolumn{2}{|c|}{ Lignite Mine Bed } & \multicolumn{2}{|c|}{ Coal Dust from the Road } \\
\hline & $\begin{array}{l}\text { Number } \\
{\left[\# \mathrm{~cm}^{-3}\right]}\end{array}$ & $\begin{array}{c}\text { Mass } \\
{\left[\mathrm{mg} \mathrm{m}^{-3}\right]}\end{array}$ & $\begin{array}{l}\text { Number } \\
{\left[\# \mathrm{~cm}^{-3}\right]}\end{array}$ & $\begin{array}{c}\text { Mass } \\
{\left[\mathrm{mg} \mathrm{m}^{-3}\right]}\end{array}$ & $\begin{array}{l}\text { Number } \\
{\left[\# \mathrm{~cm}^{-3}\right]}\end{array}$ & $\begin{array}{c}\text { Mass } \\
{\left[\mathrm{mg} \mathrm{m}^{-3}\right]}\end{array}$ & $\begin{array}{l}\text { Number } \\
{\left[\# \mathrm{~cm}^{-3}\right]}\end{array}$ & $\begin{array}{c}\text { Mass } \\
{\left[\mathrm{mg} \mathrm{m}^{-3}\right]}\end{array}$ \\
\hline Average & 49.84 & 0.15 & 63.80 & 0.17 & 21.84 & 0.08 & 56.80 & 0.43 \\
\hline Median & 49.84 & 0.13 & 67.93 & 0.14 & 21.90 & 0.06 & 58.48 & 0.42 \\
\hline Standard Deviation & 7.74 & 6.73 & 19.14 & 0.10 & 2.56 & 0.07 & 19.09 & 0.19 \\
\hline $\begin{array}{l}\text { Particle Diameter }[\mu \mathrm{m}] \\
\text { CMD/MMD }\end{array}$ & 1.28 & 6.73 & 3.05 & 12.86 & 1.28 & 2.13 & 3.28 & 11.97 \\
\hline Average Particle Size $[\mu \mathrm{m}]$ & 0.77 & 1.71 & 0.89 & 11.97 & 0.83 & 3.78 & 3.05 & 5.42 \\
\hline $\begin{array}{l}\text { Maximum Particle } \\
\text { Concentration }\end{array}$ & 73.56 & 4.32 & 65.12 & 0.97 & 32.36 & 0.84 & 95.87 & 1.54 \\
\hline$\%$ of mass after sieving & n.a. & 5.31 & n.a. & 0.96 & n.a. & 2.41 & n.a. & 16.81 \\
\hline $\begin{array}{l}\text { Suspended } \% \text { of total } \\
\text { sample mass }\end{array}$ & n.a. & 0.03 & n.a. & 0.01 & n.a. & 0.01 & n.a. & 0.32 \\
\hline
\end{tabular}

n.a. = not applicable 
Table 4 Sample 5-8.

\begin{tabular}{|c|c|c|c|c|c|c|c|c|}
\hline \multirow[b]{3}{*}{ Sample Name } & \multicolumn{2}{|c|}{5} & \multicolumn{2}{|c|}{6} & \multicolumn{2}{|c|}{7} & \multicolumn{2}{|c|}{8} \\
\hline & \multicolumn{2}{|c|}{ Coal Mine } & \multicolumn{2}{|c|}{ Road in the Coal Mine } & \multicolumn{2}{|c|}{ Dumping Site for Ash } & \multicolumn{2}{|c|}{ Dumping Site for Gypsum } \\
\hline & $\begin{array}{l}\text { Number } \\
{\left[\# \mathrm{~cm}^{-3}\right]}\end{array}$ & $\begin{array}{c}\text { Mass } \\
{\left[\mathrm{mg} \mathrm{m}^{-3}\right]}\end{array}$ & $\begin{array}{l}\text { Number } \\
{\left[\# \mathrm{~cm}^{-3}\right]}\end{array}$ & $\begin{array}{c}\text { Mass } \\
{\left[\mathrm{mg} \mathrm{m}^{-3}\right]}\end{array}$ & $\begin{array}{l}\text { Number } \\
{\left[\# \mathrm{~cm}^{-3}\right]}\end{array}$ & $\begin{array}{c}\text { Mass } \\
{\left[\mathrm{mg} \mathrm{m}^{-3}\right]}\end{array}$ & 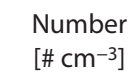 & $\begin{array}{c}\text { Mass } \\
{\left[\mathrm{mg} \mathrm{m}^{-3}\right]}\end{array}$ \\
\hline Average & 30.91 & 0.15 & 34.85 & 0.36 & 68.74 & 0.59 & 31.19 & 0.08 \\
\hline Median & 30.35 & 0.12 & 35.77 & 0.34 & 67.93 & 0.54 & 30.98 & 0.06 \\
\hline Standard Deviation & 4.92 & 0.10 & 7.44 & 0.19 & 17.79 & 0.25 & 7.46 & 0.07 \\
\hline $\begin{array}{l}\text { Particle Diameter }[\mu \mathrm{m}] \\
\text { CMD/MMD }\end{array}$ & 5.10 & 1.98 & 1.28 & 3.28 & 3.05 & 2.12 & 3.05 & 1.84 \\
\hline Average Particle Size $[\mu \mathrm{m}]$ & 1.84 & 3.78 & 3.60 & 4.07 & 2.64 & 2.45 & 0.89 & 3.05 \\
\hline $\begin{array}{l}\text { Maximum Particle } \\
\text { Concentration }\end{array}$ & 46.02 & 0.79 & 58.48 & 1.75 & 132.14 & 1.74 & 45.42 & 1.75 \\
\hline$\%$ of mass after sieving & n.a. & 1.05 & n.a. & 6.55 & n.a. & 10.32 & n.a. & 3.28 \\
\hline $\begin{array}{l}\text { Suspended \% of total } \\
\text { sample mass }\end{array}$ & n.a. & 0.01 & n.a. & 0.10 & n.a. & 0.26 & n.a. & 0.01 \\
\hline
\end{tabular}

n.a. = not applicable

Table 5 Sample 9-11.

\begin{tabular}{|c|c|c|c|c|c|c|}
\hline \multirow[b]{3}{*}{ Sample Name } & \multicolumn{2}{|c|}{9} & \multicolumn{2}{|c|}{10} & \multicolumn{2}{|c|}{11} \\
\hline & \multicolumn{2}{|c|}{ Dumping Site for Fresh Ash } & \multicolumn{2}{|c|}{ Capping Soil } & \multicolumn{2}{|c|}{ Ash from Tušimice Powerplant } \\
\hline & $\begin{array}{l}\text { Number } \\
{\left[\# \mathrm{~cm}^{-3}\right]}\end{array}$ & $\begin{array}{c}\text { Mass } \\
{\left[\mathrm{mg} \mathrm{m}^{-3}\right]}\end{array}$ & $\begin{array}{l}\text { Number } \\
{\left[\# \mathrm{~cm}^{-3}\right]}\end{array}$ & $\begin{array}{c}\text { Mass } \\
{\left[\mathrm{mg} \mathrm{m}^{-3}\right]}\end{array}$ & $\begin{array}{l}\text { Number } \\
{\left[\# \mathrm{~cm}^{-3}\right]}\end{array}$ & $\begin{array}{c}\text { Mass } \\
{\left[\mathrm{mg} \mathrm{m}^{-3}\right]}\end{array}$ \\
\hline Average & 37.69 & 0.27 & 27.98 & 0.18 & 44.06 & 0.62 \\
\hline Median & 37.98 & 0.22 & 27.73 & 0.14 & 27.73 & 0.53 \\
\hline Standard Deviation & 16984 & 0.20 & 4.31 & 0.15 & 14.11 & 0.37 \\
\hline $\begin{array}{l}\text { Particle Diameter }[\mu \mathrm{m}] \\
\text { CMD/MMD }\end{array}$ & 3.05 & 2.64 & 3.05 & 12.86 & 3.28 & 2.64 \\
\hline Average Particle Size $[\mu \mathrm{m}]$ & 2.64 & 2.46 & 1.17 & 2.83 & 0.89 & 4.07 \\
\hline $\begin{array}{l}\text { Maximum Particle Concen- } \\
\text { tration }\end{array}$ & 107.14 & 1.62 & 41.19 & 1.44 & 80.39 & 2.83 \\
\hline$\%$ of mass after sieving & n.a. & 16.32 & n.a. & 0.41 & n.a. & 6.77 \\
\hline $\begin{array}{l}\text { Suspended } \% \text { of total } \\
\text { sample mass }\end{array}$ & n.a. & 0.19 & n.a. & 0.00 & n.a. & 0.18 \\
\hline
\end{tabular}

n.a. = not applicable

persed matter from the total mass of dry sample as it was found in the resuspension chamber experiments.

The APS analysis showed that the flue ash, after its suspension, reaches the highest number and mass concentrations. As far as the size distribution is concerned, it also contains very small particles, $1 \mu \mathrm{m}$ and smaller. In the North Bohemian mine, therefore, flue ash represents the largest potential source of aerosol particles, although it is stored only in a small number of locations. If not quickly covered with overburden soil, the flue ash dumps turn into major sources of aerosol particles. Another significant aerosol source is the lignite dust deposited on the mine roads. Generally speaking, the potential of a given aerosol source depends on what part of the total area of the mine it occupies. From this point of view, the roads are most probably the largest source of aerosol pollution.
Fig. 16 shows the relation of the individual size fractions of lignite to temperature and humidity. The relation is expressed as the ratio of individual size fractions to the TSP $(100 \%)$. The data was obtained using the HI gravimetric method. Five measurements were made for each set of temperature-humidity conditions. The sample weight for each dispersion was $10 \mathrm{mg}$. Fig. 16 shows the mass of lignite size fractions for different temperature and humidity conditions. The lignite aerosol mass slowly increased with relative humidity in comparison with inorganic aerosol (Hu et al 2010). The largest increase in mass was identified at $30{ }^{\circ} \mathrm{C}$ and a $\mathrm{RH} 80 \%$ for the fractions $\mathrm{PM}_{2.5}$ and $\mathrm{PM}_{1}$. The fraction $\mathrm{PM}_{1}$ showed the highest sensitivity to humidity changes at $30^{\circ} \mathrm{C}$.

Fig. 17 shows the size distribution of particle mass expressed as ratios of individual fractions of deposited 


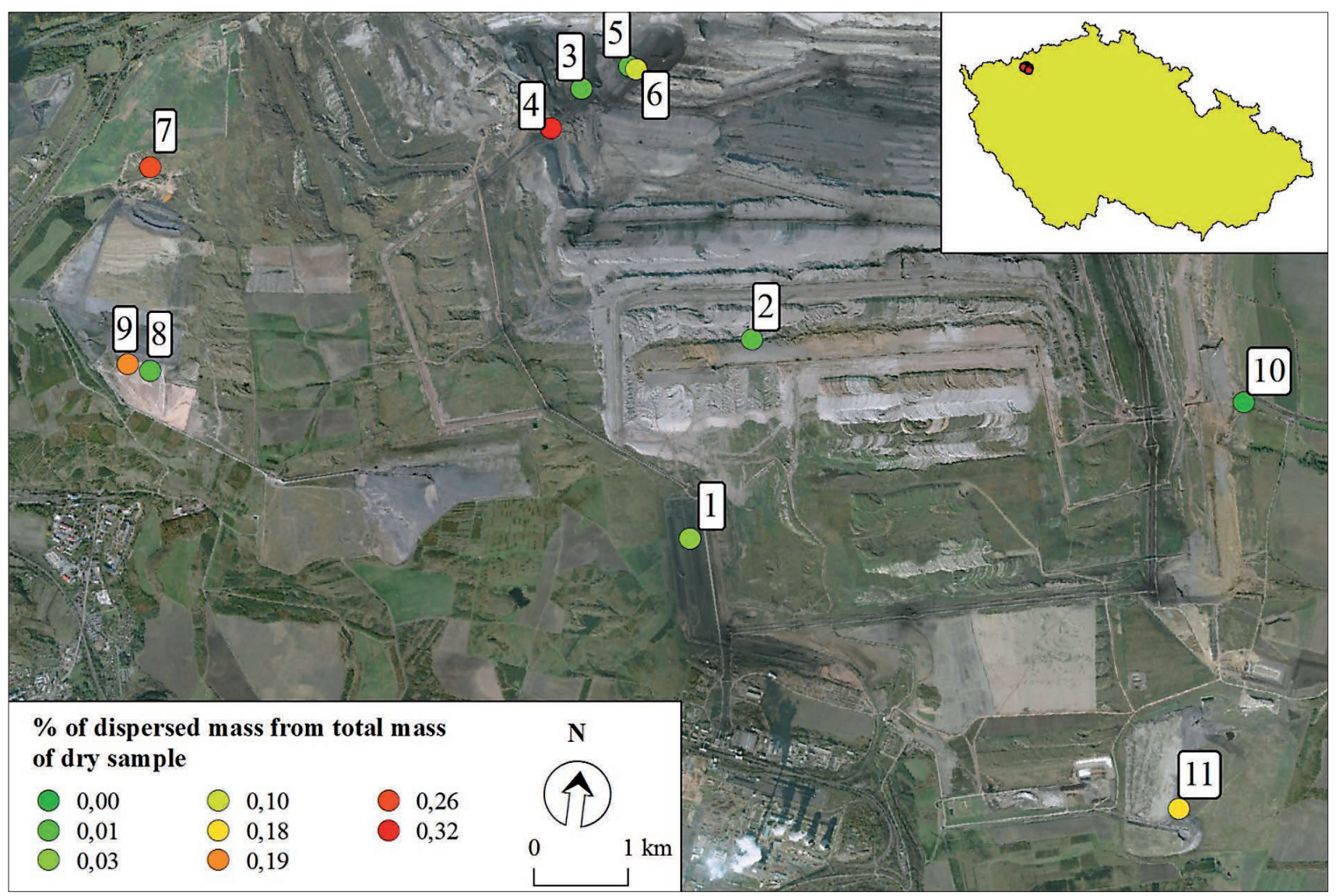

Fig. 15 Aerial view of the Nastup mine with sampling locations marked. 1 - homogenization dump, 2 - overburden damping machine, 3 - mine bed, 4 - dust deposited on the road surface, 5 - location of mining, 6 - dust deposited on the road surface, 7 - flue ash dump, 8 - gypsum dump, 9 - flue ash, 10 - overburden, 11 - Tusimice flue ash.

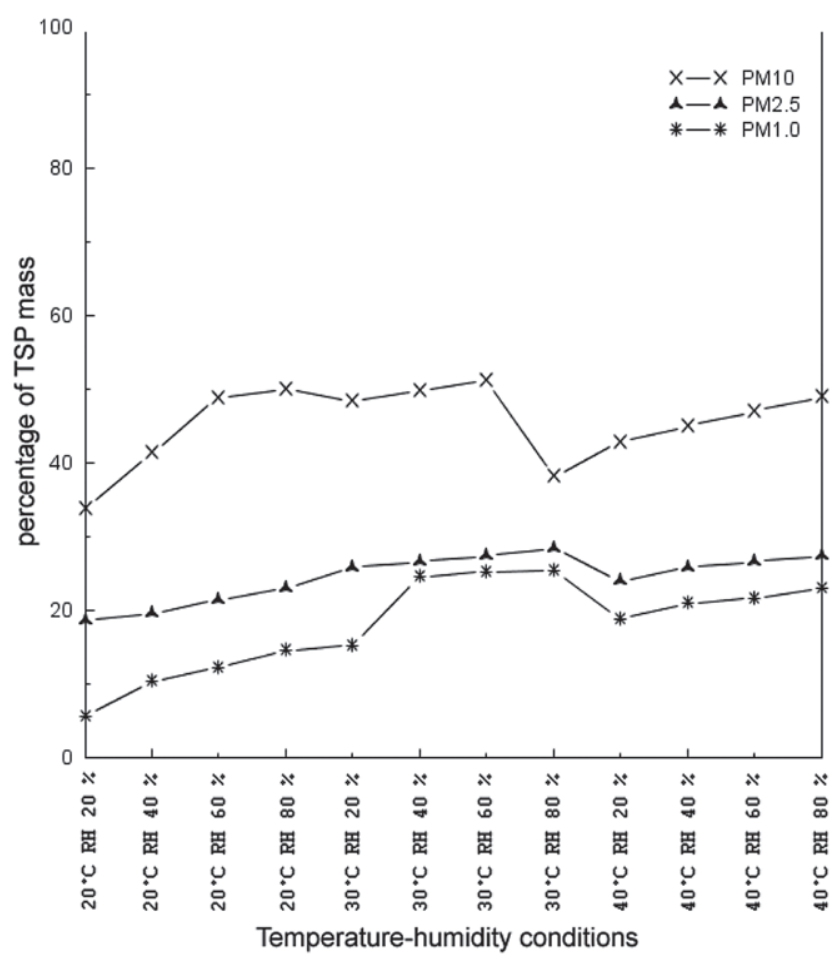

Fig. 16 Mass of the individual size fractions of lignite under different temperature-humidity conditions relative to TSP [\%]. matter to the TSP using the data from the HI and PCIS at $20{ }^{\circ} \mathrm{C}$ and a RH $50 \%$. The TSP from the PCIS was calculated as the sum of all mass values. Fraction $\mathrm{HI} \mathrm{PM}_{2.5}$ reached the value of $17 \%$ and $\mathrm{PM}_{1} 10 \%$.

Graphs of size distributions of mass concentration of individual fractions of flue ash are shown in Fig. 18. They are expressed as ratios of the individual fractions to the TSP. Flue ash contains higher amounts of particles in size fractions $\mathrm{PM}_{2.5}$ and $\mathrm{PM}_{1}$. The difference of 2.5-1 $\mu \mathrm{m}$ reaches $10 \%$ and the PCIS fraction $2.5-1 \mu \mathrm{m}$ also reaches $10 \%$. Flue ash contains a higher proportion of the finer fractions $2.5-1,1-0.5$ and $0.5-0.25$. These results indicate that flue ash is a greater health hazard for the population of the North Bohemian Lignite Basin than the lignite mining itself. Loosely stored flue ash can easily turn airborne during dry and windy summer periods and in this way becomes a hazardous source of aerosol if it is not quickly covered with soil.

Elemental analysis of samples of flue ash was carried out using SEM/EDS. The resulting images are shown in Figs 19 and 20 and elemental composition summarized in Table 6. The main component of the $\mathrm{PM}_{10}$ fraction is mullite $\mathrm{Al}_{6} \mathrm{Al}_{4}\left(\mathrm{O}_{3}\right)\left(\mathrm{O}_{1 / 2}, \mathrm{OH}, \mathrm{F}\right) \mathrm{Si}_{3} \mathrm{O}_{16}$, which is most frequently found in flue ashes. The $\mathrm{PM}_{2.5}$ fraction was dominated by sulphides, pyrites, pyrrhotites and polytypes of 

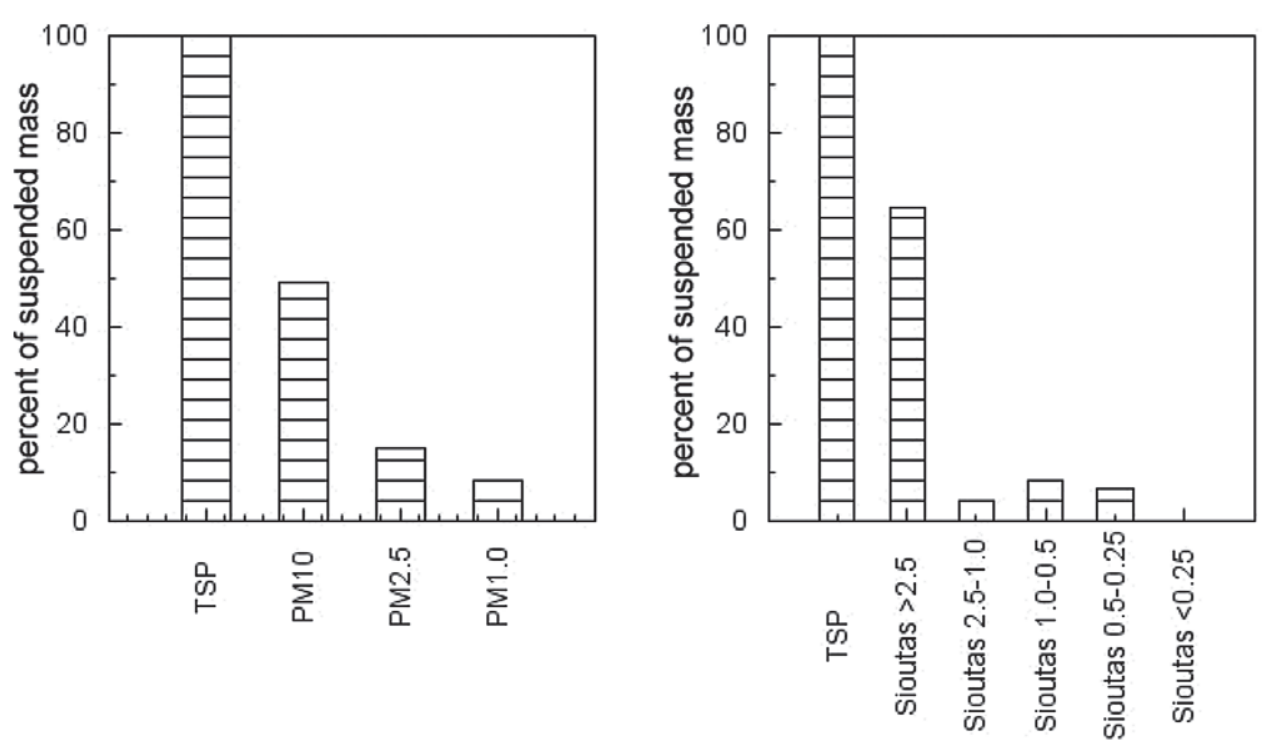

Fig. 17 Size distribution of particle mass in lignite sample, as a ratio of the individual fractions to the TSP, data from $\mathrm{HI}$ and $\mathrm{PCIS}\left(20^{\circ} \mathrm{C}\right.$ and $\left.\mathrm{RH} 50 \%\right)$.
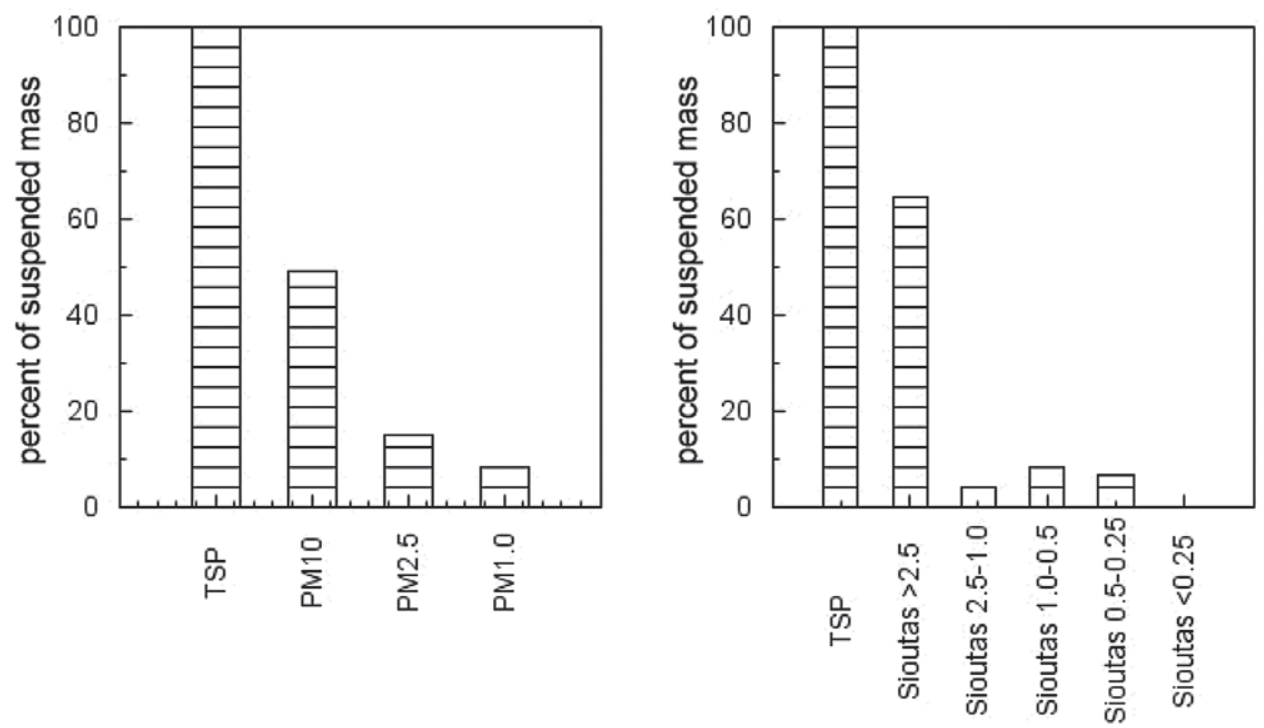

Fig. 18 Size distribution of particle mass in flue ash sample, as a ratio of the individual fractions to the TSP, data from $\mathrm{HI}$ and PCIS $\left(20^{\circ} \mathrm{C}\right.$ and RH $\left.50 \%\right)$.

sulphide. The $\mathrm{PM}_{1}$ fraction contained the highest percentage of sodium, the most probable particle composition being sodium glass.

The analysis of the most frequent grains captured on the PCIS from fraction A $(>2.5 \mu \mathrm{m})$ identified mullite. The analysis of fractions PCIS B $(2.5-1.0 \mu \mathrm{m})$ and PCIS C $(1.0-0.5 \mu \mathrm{m})$ identified quartz. PCIS D $(0.5-0.25 \mu \mathrm{m})$ contained mostly pyrites and SIO E $(<0.25 \mu \mathrm{m})$ mostly as sodium glass. Fig. 19 shows an SEM image of the filter with the deposit of aerosol of flue ash, size fraction B $(2.5-1.0 \mu \mathrm{m})$. Agglomerations of particles on the filter are visible at the sites labelled 1, 2, 3 and 4 .

\section{Conclusions}

A resuspension chamber was built as a part of the author's doctoral work. The chamber was designed to dis- perse loose solids in air under laboratory conditions of regulated temperature and relative humidity. The aerosol produced can be observed using APS or by a gravimetric method of sampling. The chamber enables us to simultaneously study the size distributions of atmospheric aerosol samples and their chemical composition.

The resuspension chamber was used for the dispersion of samples at $20{ }^{\circ} \mathrm{C}$ and a $\mathrm{RH} 50 \%$ collected from various parts of a North Bohemian lignite mine. The samples were subsequently analyzed using APS with a time resolution of $5 \mathrm{~s}$. Average profiles of size distributions of particle number and mass concentration were determined for the individual samples. It was found that flue ash reached the highest mass concentrations after the dispersion: up to $2.7 \%$ of the dispersed sample weight, and $0.26 \%$ of the total mass of the sample, became airborne. In contrast, gypsum reached only low mass concentrations after its dispersion in the resuspension 


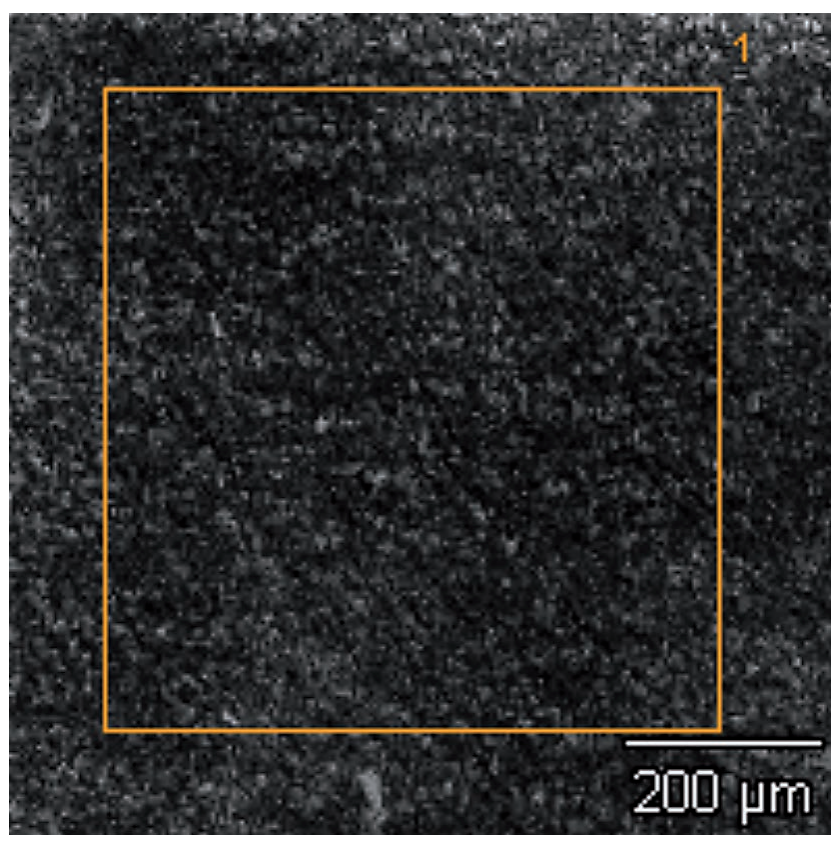

Fig. 19 Electron microscope image of the filter with deposit of flue ash aerosol, size fraction TSP.

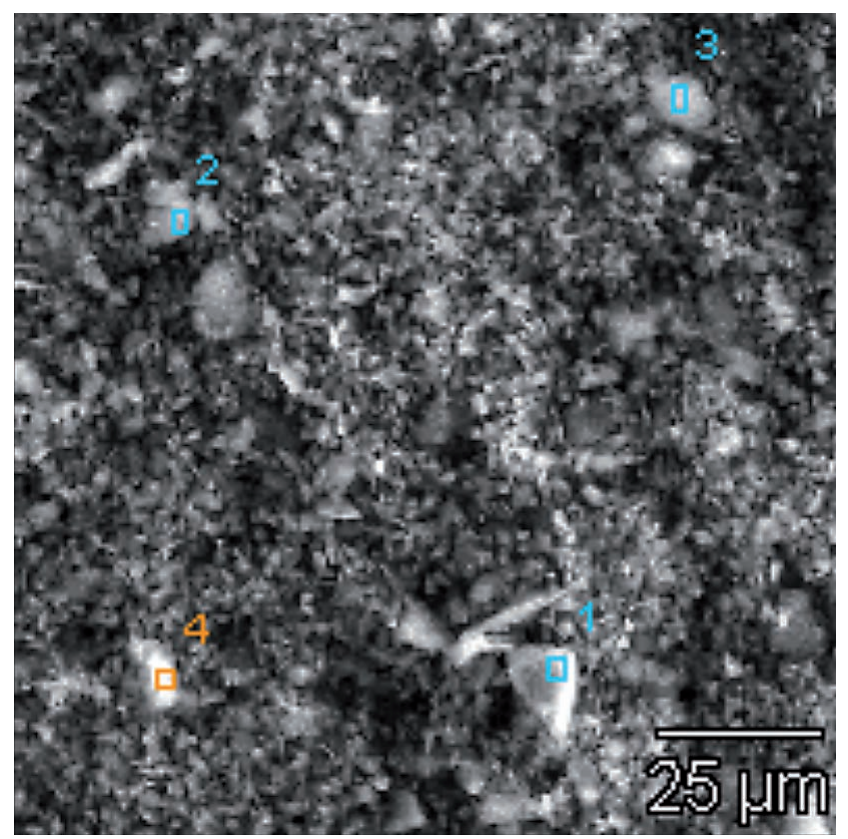

Fig. 20 Image of the filter with deposit of flue ash aerosol, size fraction PCIS B $(2.5-1.0 \mu \mathrm{m})$.

Table 6 Percentage of elements in TSP, $\mathrm{PM}_{10}, \mathrm{PM}_{2.5}, \mathrm{PM}_{1}$ and SIOUTAS $>2.5,2.5-1.0,1.0-0.5,0.5-0.25$ and $<0.25 \mu \mathrm{m}$.

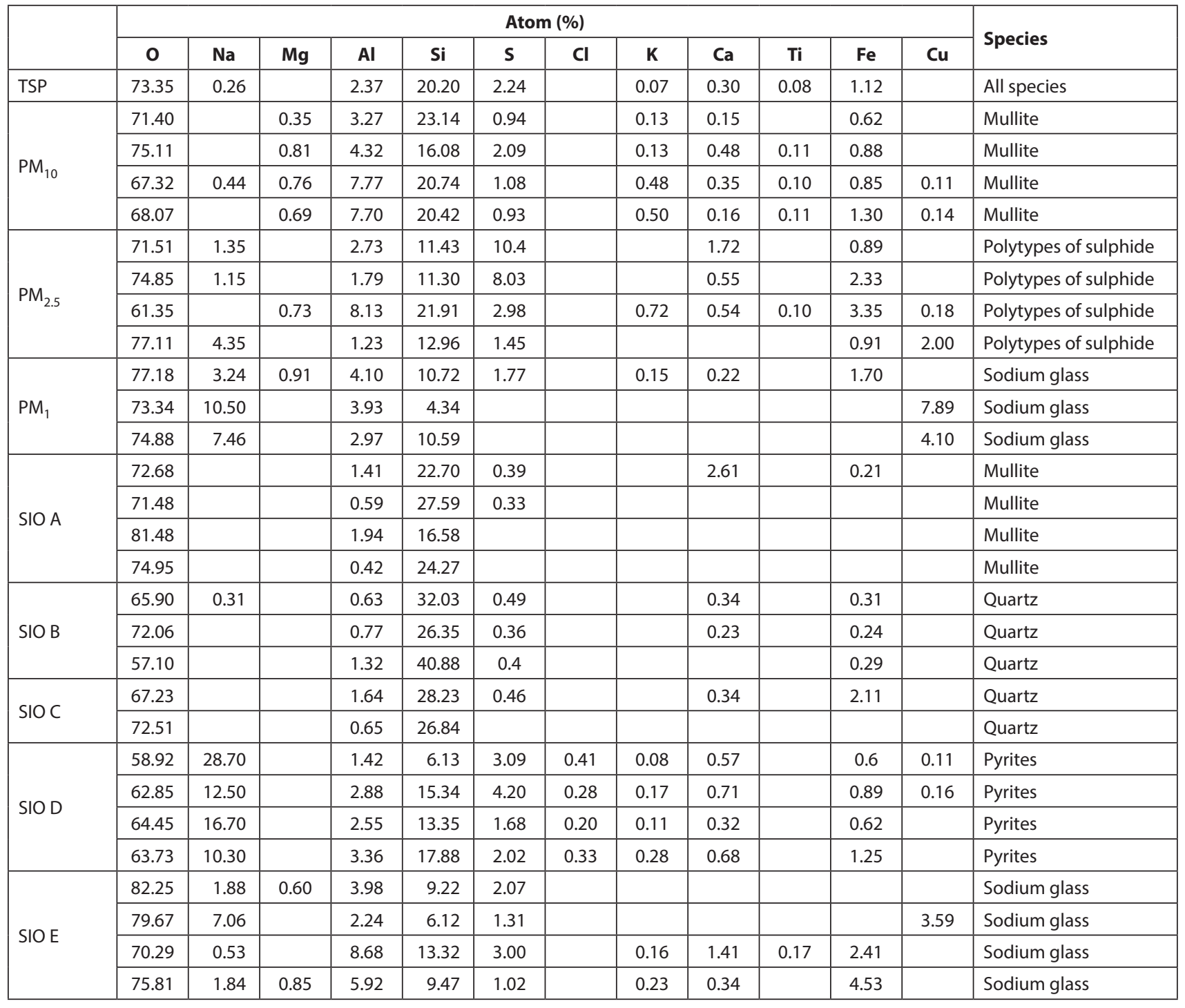


chamber: $0.34 \%$ of the dispersed sample weight $(0.01 \%$ dispersed matter of the total mass of dry sample), and overburden soil showed the lowest mass concentrations after the suspension (only $0.001 \%$ dispersed matter from the total mass of the dry sample). Dust particles from the mine roads and currently exploited locations will probably contribute the most to the total mass concentration of the atmospheric aerosol in the region studied because the mass concentrations of dust reached up to $1.88 \%$ of the dispersed matter and the areas producing such dust form the largest part of the total area of the mine.

The lignite and flue ash samples were gravimetrically analyzed using $\mathrm{HI}$ under various temperature-humidity conditions. We found that the ratio of individual size fractions to TSP increased with increase in relative humidity, most significantly with the fraction $\mathrm{PM}_{10}$ at $30^{\circ} \mathrm{C}$ and $\mathrm{RH} 60 \%$. At $40{ }^{\circ} \mathrm{C}$, the $\mathrm{PM}_{10}$ fraction increased in mass only slightly. The $\mathrm{PM}_{1}$ fraction showed the greatest tendency to increase in mass at $30{ }^{\circ} \mathrm{C}$ and $\mathrm{RH} 40-80 \%$.

A profile of the size distribution of particle mass was obtained from the gravimetric analysis of lignite and flue ash samples at $20^{\circ} \mathrm{C}$ and RH $50 \%$. The analysis revealed higher mass values at smaller fractions (2.5-1, 1-0.5 and $0.5-0.25 \mu \mathrm{m}$ ) of flue ash in comparison to the same fractions of lignite.

The filters with flue ash deposits were chemically analyzed using an electron microscope. The analysis showed elemental differences in the fractions studied. Dominant species were identified in the individual fractions (mullite, pyrites, polytypes of sulphide and sodium glass).

\section{Acknowledgements}

This work was funded by the Grants Agency of Charles University, Prague, under the project "Determination of the re-suspendable fraction in samples of soil and street dust using a resuspension chamber" No. 40307 and by the Czech Ministry of Environment under the project "Determination of the concentrations of atmospheric aerosol with high size and time resolution for the purpose of sources location and toxicity estimate" No. VaV SP/ 1a3/149/08.

The author would like to thank R. Nedbalek and M. Eng, who made it possible for us to collect samples at the Nastup coal strip mine in Northern Bohemia, and J. Brejcha and M. Eng for the density measurements on the samples.

\section{REFERENCES}

American Society for Testing and Materials (1984) Effectiveness of Dedusting Agents for Powdered Chemicals, ASTM Designation D-D4331-84, ASTM Committee D22.04 on Workplace Atmospheres, ASTM: West Conshohocken, PA, pp 448-452.

Andreasen AHM, Hofman-Bang H, Rasmussen NH (1939) On the ability to be dusty of materials. Kolloid Z 86: 70-77.
Breum NO (1999) The rotating drum dustiness tester: variability in dustiness in relation to sample mass, testing time, and surface adhesion Annual Occup Hyg 43: 557-566.

Busacca A, Stetler L, Horning L, Barry R, Wagoner L, Saxton K, Ashbaugh LL (1997) Development of a PM10 'dustiness index' to assess wind erodibility of soils of the Columbia Plateau, Pacific Northwest, Wind Erosion International Symposium-Workshop, Manhattan, KS, 3-5 June 1997.

Chen YC, Barber EM, Zhang Y, Besant RW, Sokhansanj S (1999) Methods to measure dust production and deposition rates in buildings. J Agr Eng Res 72: 329-340.

Cheng L (1973) Formation of respirable dust at belt conveyor transfer points. Am Ind Hyg Assoc J 34: 540-546.

Concessio NM, Jäger-Waldau R, Hickey AJ (1997) Aerosol delivery from an active emission multi-single dose dry powder inhaler. Part Sci Tech 15: 51-63.

Dahmann D, Hartfiel K, Mocklinghoff K (1997) A procedure for the realistic determination of the dust-making inclination of waste. Gefahr Reinhalt Der Luft 57: 503-507.

Deichman WB, Dustshaker A (1944) J Ind Tox 26: 334-335.

Dockery DW, Pope CA, Xu X, Spengler JD, Ware JH, Fay ME, Ferris BG, Speizer FE (1993) An association between air pollution and mortality in six U.S. cities. New Engl J Med 329: 1753-1808.

Graham JA, Miller FJ, Davies DW, Hiteshew ME, Walsh LC (1985) Inhalation studies of Mt. St. Helens volcanic ash in animals. I., Introduction and exposure system. Env Res 37: 61-71.

Heitbrink WA, Baron PA, Willeke K (1992) An investigation of dust generation by free falling powders. Am Ind Hyg Assoc. J 53: 617-624.

Hindle M, Byron PR (1995) Size distribution control of raw materials for dry powder inhalers using the aerosizer with the aero-disperser. Pharm Tech 19: 64-78.

Hirano T, Kiyota M, Aiga I (1995) Physical effects of dust on leaf physiology of cucumber and kidney bean plants. Env Poll 89: 255-261.

Hu D, Qiao L, Chen J, Ye X, Yang X, Cheng T, Fang W (2010) Hygroscopicity of inorganic aerosols: Size and relative humidity effects on the growth factor. Aerosol Air Qual Res 10: 255-264.

Lanning JS, Boundy MG, Leith D (1995) Validating a model for the prediction of dust generation Part Sci Tech 13: 105-116.

Lewis S (1995) Solid particle penetration into enclosures. J Haz Mat 43: 195-216.

Li XW, Owen JA (1996) A dust segregation rate test system. J Env Sci Health A 31: 2533-2545.

Marple VA, Rubow KL, Turner W, Spengler JD (1987) Lowflowrate sharp-cut impactors for indoor air sampling: Design and calibration. J Air Pollut Control Assoc 37: 1303-1307.

Misra C, Singh M, Shen S, Sioutas C, Hall PM (2002) Development and evaluation of a personal cascade impactor sampler (PCIS). J Aerosol Sci 33: 1027-1047.

Morales JR, Dinator MI, Llona F, Saavedra J, Falabella F (1994) Sample preparation for archeological materials for PIXE analysis. J Rad Nucl Chem L 187: 79-89.

Muhle H, Bellmann B, Creutzenberg O, Heinrich U, Ketkar M, Mermelstein R (1990) Dust overloading of lungs after exposure of rats to particles of low solubility: comparative studies. J Aerosol Sci 21: 374-377.

Newman SP (2004) Dry powder inhalers for optimal drug delivery. Expert Opin Biol Ther 4: 23-34.

Newman SP, Busse WW (2002) Evolution of dry powder inhaler design, formulation and performance. Res Med 96: 293-304.

Ning Z, Sioutas K (2010) Atmospheric Processes Influencing Aerosols Generated by Combustion and the Inference of Their Impact on Public Exposure A Review. Aerosol Air Qual Res 10: 43-57. 
Pope CA, Thun MJ, Namboodiri MM, Dockery DW, Evans JS, Spengler FE, Haetch CW (1995) Particulate air pollution as a predictor of mortality in a prospective study of U.S. adults. Am J Res Critical Care Med 151: 669-674.

SAE Handbook (1943) 1943 Edition, Page 716.

Schwartz J, Dockery DW, Neas LM (1996) Is daily mortality associated specifically with fine particles? J Air Waste Manage Assoc 46: 927-939.

Sonkin LS, Lipton MA, Van Hoeson D (1946) An apparatus for dispersing finely divided dusts. J Ind Hyg Tox 28: 273-275.
Sutter SL, Johnson JW, Mishima J (1982) Investigation of accident-generated aerosols: Releases from free-fall spills. Am Ind Hyg Asso J 43: 540-543.

Thimmaiah D, Hovorka J, Hopke PK (2009) Source apportionment of winter submicron Prague aerosols from combined particle number size distribution and gaseous composition data. Aerosol Air Qual Res 9: 209-236.

Vincent JH, Aitken RJ, Mark D (1993) Porous plastic foam filtration media: penetration characteristics and applications in particle size-selective sampling. J Aerosol Sci 24: 929-944. 